\title{
Integrative Instruction Model of Indonesian History and Local History
}

\author{
M. Fakhruddin ${ }^{1}$, Firdaus Hadi Santosa ${ }^{2}$ \\ \{mfakhruddin@unj.ac.id ${ }^{1}$, firdaushadi@unj.ac.id ${ }^{2}$ \} \\ ${ }^{1,2}$ Department of History Education, Faculty of Social Science, State University of Jakarta, Indonesia
}

\begin{abstract}
The integrative instruction model of Indonesian History in this study is an instruction model design that integrates Indonesian History with local history in Jakarta, Depok, and Tangerang. The aim is to be able to develop a model of Indonesian History instruction that would be more effective in increasing student understanding. This study applied qualitative descriptive research. The data collecting technique was conducted through observation, interviews, and documents. The data analysis was carried out using triangulation techniques. Learning Indonesian History is very important in developing the characteristics and nationalism of students. Efforts to improve and maximize students' understanding of Indonesian History material can be done through the integration of local history in the immediate environment of the student's residence. In this case, local history has a closeness and local perspective in the context of national history which is studied in the study of Indonesian History.
\end{abstract}

Keywords: Indonesian History, Integrative instruction model, local history

\section{Introduction}

Indonesian History subject is the result of the development of historical subjects in the 2013 curriculum, by placing Indonesian History subjects as compulsory subjects. This shows that the subjects of Indonesian History are considered important in the structure of the 2013 curriculum, although previously history subject was considered less important [1]. Even before this curriculum was compiled, history learning had to be placed in a very important position, it considered that the study of history or more importantly history education was the answer to how to prepare life of the nation. This is not only believed in Indonesia but also in other countries have a common perception of the importance of historical education in the curriculum of education [2]. The position of learning history is indeed supposed to be important learning, given that history learning can shape the character and foster historical awareness that is important for strengthening nationalism.

Sardiman argued that learning history is a process of activity that encourages and stimulates students to reconstruct and gain historical knowledge which then occurs the process of internalizing values related to various aspects of society and nationality. In addition to that is living human values, to bring changes in behavior as the process of developing the personality or character of students [3]. 
Learning history trains students to be able to think critically and deeply so that they can absorb the values in every historical event so that it is important for the development of students' character[4]. Learning history is also important in forming human beings who have humanity[5]. Learning history is more important to shape the mindset of students, to be able to understand a historical event based on the perspective according to the context of the era, and analyze it by adjusting in human values. Through learning history, will foster historical awareness, which is only achieved if someone understands its history [6]. At the conceptual level, there are a lot of opinions that learning history is indeed important and very much needed by students, but at the implementation or application stage, it still raises different interpretations.

Learning the history of Indonesia as a national history with all of the material in this subject only focuses on historical events that are national in scope so that students often feel they do not have a closeness to their neighborhood and not familiar with it. This, of course, makes it difficult for students to understand the essence of the history learning material delivered because there is no emotional connection, or even though there is very little and far from their contexts. So that local history is needed to complete historical studies that are not discussed in the study of history which is national in scope. Given that local history is history that depends on its geographical scope, so it does not only discuss events or large figures, but also ordinary people who struggle with problems that are human and natural [7]. So that local history has autonomy which will make a major contribution to the understanding of national history that is general and centralized.

Meanwhile, concerning integrated history learning, some notions of integrated learning are learning that explicitly links several ideas and abilities from several levels [8]. Integrated learning is also learning that links several areas of learning that are linked to specific themes [9]. So that integrated learning can be a place for the implementation of Indonesian History learning which is still in nature and only includes historical studies that are national and general, by integrating local history which is more specific.

The nature of local history that focuses on the more specific problems around it can be a pioneer in solving problems that are not solved in national history. This local history can be the main capital to strengthen the national history of Indonesia, especially to strengthen the unity and integrity of Indonesia with all its uniqueness[10]. So it seems to be a necessity that Indonesian History learning also integrates local history in the surrounding environment. This shows that the role of local historical material is not only as a compliment but as an effort and means of cultural inheritance for future generations. But the problem is that there has not been a conscious and structured effort to implement a learning model that fits that goal. There are difficulties and obstacles for teachers to integrate local history material without a framework or reference in its application in school. As the research conducted by Apriyanto et al [11], the main problem in integrating local history into Indonesian historical material is the limited availability of resources. But whether it also happens in areas that are rich in historical events that have enough historical sources such as in Jakarta, Depok, and Tangerang.

\section{Method}

The study was conducted using qualitative naturalistic design, so it is expected to reveal various qualitative information with a careful and meaningful analysis description. In each object will be seen trends, thought patterns, irregularities, as well as the appearance of behavior and its integration as in genetic case studies [12]. Because the problem and focus of 
the research have been determined before the collection of field data, this type of research strategy can be more specifically called embedded study research [13].

Research data sources are teachers from thirty-three high schools in Jakarta, Depok, and Tangerang. Questions related to the implementation of history learning integration of local history in Indonesian History subject. Data collection is done through in-depth interview techniques, non-participant observation, and document notes. The sampling technique is done by purposive sampling. To guarantee the validity of the data collected, the informant review technique is used or feedback from the informants. Data analysis techniques using an interactive analysis model that includes data reduction activities, data presentation, verification, and concluding. In the process, carried out in an interactive form as a process that continues, repeats, and continues to form a cycle [14].

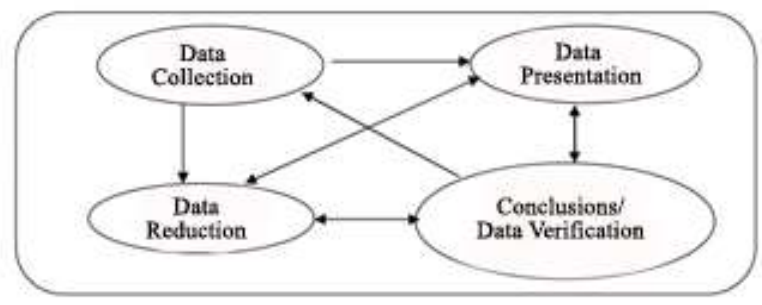

Fig.1. The component of Interaktive Model data analysis

\section{Result and Discussion}

The implementation of Indonesian History learning in schools has a variety of differences caused by several factors, including the teacher and the environment. In this article, the data collected from several schools in Jakarta, Depok and Tangerang, the overall teacher background of $93.9 \%$ are teachers with a historical background.

Based on research data regarding the experience of integrating local history material in Indonesian History learning $87.9 \%$ of the total number of teachers used as research objects have integrated local history material in Indonesian History learning. As for the local history material integrated into learning in the form of the origin of the name of the region, the name of the street, or the name of a particular place in the neighborhood where students live. Besides that the discussion about the figures who are considered to have a significant influence or role for the localization around the neighborhood where students live. Some also integrate local historical material related to the socio-cultural community.

Each local history material that is integrated follows the discussion that can be in KI (core competency) and KD (base competency) which are then adjusted to the topic being studied. Each teacher has a different way of integrating local history material in the learning of Indonesian History, some of the ways that are intended are the assignment of the teacher to make local history maps, toponymy studies or tracking the names of specific places or regions, making visits or observations to locations or regions in question as well as regional museums in the region, study literacy through local history books and correlate them with Indonesian historical events in general, and provide additional explanations about local historical figures when discussing national figures and so on. 


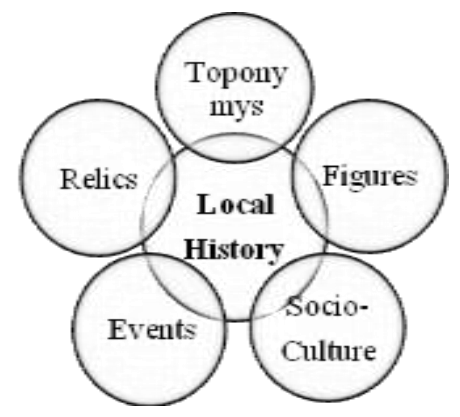

Fig. 2. Conceptual maps of types of local history based on interview results

The basis of integration carried out in each school is based on several reasons related to the need to integrate with learning Indonesian History. Learning local history is considered to be able to strengthen the understanding of Indonesia's national history better, as a means of environmental introduction, local history can complement Indonesia's national history. It creates students more respect for the region and the country to be proud as Indonesian citizens while increasing awareness that life cannot be separated from the history that is around. Besides, there is also based on that learning local history is not only learning the negative impacts of history that occur as a result of colonialism, but also the positive impact of each historical event or journey that occurs around it.

Table 1. Several local history materials which are studied in Indonesian History study

\begin{tabular}{lll}
\hline \multicolumn{1}{c}{ Jakarta } & \multicolumn{1}{c}{ Depok } & \multicolumn{1}{c}{ Tangerang } \\
\hline PetukanganToponymy, Pondok & History of Margonda, Tole & History of Daan Mogot, \\
Gede dan Klender, historical & Iskandar, historical events: & Lengkong war, history of \\
figures: Datuk Tonggara, Si & Gedoran Depok, Tugu & places: BSD, Serpong, Taman \\
Pitung, M. Saidi, K.H. Noer Ali, & Sawangan, Belanda Depok & Seribu Pahlawan, Setu \\
$\begin{array}{l}\text { M. Husni Thamrin, Halim } \\
\text { Perdana Kusuma, also historical } \\
\text { events: Entong Gendut Revolt, }\end{array}$ & people history, also historical & Babakan, Tangsel, Klenteng, \\
Mardjikers peoples, Lapangan & & Ciputat Veterans Building \\
Ikada, dan Betawi ethnic history & & \\
\hline
\end{tabular}

The importance of local history to be integrated into the learning of Indonesian History is related to students' awareness that they have their pasts to bring pride and awareness of the importance of their history, environment, and culture [15]. If students only study Indonesian History, students will only lose interest in studying history that is too general and far from their environment. In learning history such as this will make students bored because it only learns the history that occurs in other areas, whereas in their area many historical events occur [16].

The results of this study indicate that local history is considered to be able to provide a new dimension in studying Indonesian History. If seen as a whole, through the integration of 
local history in Indonesian History learning students are invited to learn contextually by presenting learning subjects that are directly related to students and their environment [17]. Surely this is a good thing for students given that contextual learning can increase student motivation and learning outcomes[18], and critical thinking skills [19].

However, in the implementation of local history learning in each school, the level of integration of local history in Indonesian History has not yet reached the conscious and structured effort. The absence of structured planning that causes a mismatch between what is planned in the Syllabus and RPP (Lesson Plan) with the learning process. Therefore, although each teacher already has a perception that local history is important to convey, it seems that it is not yet at the planned and structured stage.

The integration of local history in learning Indonesian History does not seem easy, although each teacher considers that this integration of local history is important. Not only in terms of the development of Indonesian History material but also for the development of students' awareness and perspectives on local history and national history. The integration of local history into Indonesian History learning faces several obstacles including: (1) The lack of local history learning resources; (2) time constraints; (3) limitations of students' initial understanding of local history in their neighborhoods; and (4) local historical material that is not directly related to the curriculum.

Constraints related to the lack of historical sources did not only occur in areas where local history was minimal but also occurred in areas rich in local histories such as Jakarta, Depok, and Tangerang. In particular written sources in the form of books or articles of research results are indeed considered as an obstacle, but the development of historical research currently has issued many books or research related to local history, especially in some of these areas. It's just that there needs to be the seriousness of the teacher in designing learning that is integrated with local history and national history. Besides, historical sources such as museums or historical sites can also be utilized, to become a means for teachers to carry out Indonesian History learning that is integrated with local history [16],[20].

During the history learning carried out by the teacher through the integration of local history in the learning of Indonesian History, some student characteristics can be drawn from the learning. First, students' responses to the integration of local history in history learning are mostly enthusiastic even during learning students are very interested in integrated local history materials. Secondly, students' initial understanding of local history material integrated into Indonesian History learning is still lacking, most students do not understand or even know the local history that exists in the environment around their residence.

Students show enthusiasm in learning that integrates local history in Indonesian History, this illustrates that it is possible to design a learning model that can maximize this. In addition to generating new experiences and knowledge, this learning can provide a contextual dimension so that students will get to know their history and environment, to form a basis for pride in the history of their nation in general.

The lack of students' initial knowledge of their local history is also an indicator that students do not yet know the local history in the surrounding environment. This provides a reinforcing reason that the integration of local history into Indonesian History is very important concerning the benefits that local history has for the learning of Indonesian History in general.

\section{Conclusion}


Some teachers who teach Indonesian History have awareness and experience in applying local historical integration in learning history. The implementation also varies depending on the ability of the teacher and also situational learning conditions. Integration of local history in the learning of Indonesian History which is situational raises its obstacles, namely the difficulty to adjust to the syllabus and lesson plans because they are not directly contained in the curriculum. Although fact, every school has the authority to develop learning under their locality values according to the needs of the level of education units.

This shows the need for the development of an integrative learning model in the learning of Indonesian History in which integrated local history. To facilitate the implementation of historical learning that can increase understanding of local history, the estuary is finally the understanding and national awareness of Indonesia.

Acknowledgment. We thank BLU Universitas Negeri Jakarta for funding this research, also to teachers and students in several high schools in Jakarta, Depok, and Tangerang for being an informant in this research.

\section{References}

[1] Sardiman, "Posisi Sejarah Indonesia pada Kurikulum 2013," Istor. J. Pendidik. dan Ilmu Sej., vol. 11, no. 2, 2015.

[2] H. Hasan, Sejarah Lokal: Penulisan dan Pembelajaran di Sekolah. Bandung: Salamina Press, 2007.

[3] Sardiman, Pembelajaran Sejarah dan Pembangunan Karakter Bangsa, Dalam Hansiswany Kamarga dan Yani Kusmarni (Ed), Pendidikan Sejarah Untuk Manusia dan Kemanusiaan: Refleksi Perjalanan Karir Akademik Prof. DR. Said Hamid Hasan, MA. Jakarta: Bee Media Indonesia, 2012.

[4] S. H. Hasan, "The Development of Historical Thinking and Skills in The Teaching of History in the Senior Secondary School Curriculum in Indonesia," Hist. International J. Hist. Educ., vol. XI, no. 2, 2010.

[5] S. Wineburg, Berpikir Histories: Memetakan Masa Depan Mengajarkan Masa Lalu, Terj. Masri Maris. Jakarta: Yayasan Obor Indonesia, 2006.

[6] K. Amboro, "Membangun Kesadaran Sejarah Berawal dari Pemahaman," J. Hist., vol. 3, no. 2, 2015.

[7] T. Abdullah, Sejarah Lokal di Indonesia. Yogyakarta: Gajah Mada University Press, 2010.

[8] D. R. Arendale, "Understanding the Integrated Learning Course Model : Academic Transition to Tertiary Education,” International J. High. Educ., vol. 3, no. 4, pp. 1-11, 2014.

[9] Fazriyah et al, "The Effect of Integrated Learning Model and Critical Thinking Skills of Science Learning Outcomes The Effect of Integrated Learning Model and Critical Thinking Skills of Science Learning Outcomes," J. Phys., 2017.

[10] Suswandari, "Local History of Jakarta and MulticulturalAttitude ( Historical Local Study of Betawi Ethnic )," J. Educ. Teach. Learn., vol. 2, no. 1, pp. 93-100, 2017.

[11] D. Apriyanto, "Development of E-Learning Module: Historical Culture Society Based on Local Genius," J. Hist., vol. 1, no. 2, 2017.

[12] N. Muhadjir, Metodologi Penelitian Kualitatif, IV. Yogyakarta: Rake Sarasin, 2002.

[13] R. K. Yin, Studi Kasus: Desain dan Metode. Jakarta: Raja Grafindo Persada, 2009.

[14] M. M. . and S. J. Huberman, Qualitative Data Analysis, A Methods Sourcebook, 3rd ed. 
USA: Sage, 2014.

[15] A. M. Wibowo, "Pengembangan Model Pembelajaran Sejarah Lokal di SMA Kota Madiun," J. Agastya, vol. 6, no. 2, 2016.

[16] S. Prasetyo, Ryan Rezky, La Ode Ali Basri, "Pemanfaatan Sejarah Lokal sebagai Sumber Belajar Siswa di SMA Negeri 2 Kendari," J. Wahana Kaji. Pendidik. IPS, vol. 1, no. 2, pp. 144-150, 2017.

[17] C. C. Hudson and D. Ph, "Contextual Teaching and Learning for Practitioners," Syst. Cybernetics Informatics, vol. 6, no. 4, pp. 54-58, 2007.

[18] H. Qudsyi, H. E. Wijaya, and N. Widiasmara, "Effectiveness of Contextual Teaching and Learning ( CTL ) to Improve Students Achievement and Students' Self -Efficacy in Cognitive Psychology Course," Adv. Soc. Sci. Educ. Humanit. Res., vol. 164, no. January 2018.

[19] A. B. U. Nawas, "CONTEXTUAL TEACHING AND LEARNING ( CTL ) APPROACH THROUGH REACT STRATEGIES ON IMPROVING THE STUDENTS '," Proc. Res. 20th Int. Conf., no. May, pp. 10-13, 2018.

[20] S. Aktekin, "THE PLACE AND IMPORTANCE OF LOCAL HISTORY IN THE SECONDARY HISTORY," Eğitimde Kuram ve Uygur. J. Theory Pract. Educ., vol. 6, no. 1 , pp. 86-105, 2010. 